\title{
An Experimental Study on Partial Replacement of Clayey Soil with an Industrial Effluent: Stabilization of Soil Subgrade
}

\author{
Godavarthi V.L.N. Murthy ${ }^{(凶)}$, Atkuri Venkata Krishna, \\ and Vedula V.N. Prabhakara Rao \\ Department of Civil Engineering, Sri Vasavi Engineering College, \\ Tadepalligudem, Andhra Pradesh, India
}

\begin{abstract}
Rapid growth of infrastructure viz., construction of highways, embankments limits the construction on varied soil conditions. The construction sites at times pass through weak/expansive soils. In order to overcome weak and problematic sub grade world over, soil stabilization becomes inevitable. In this connection, mechanical stabilization of clayey soils is explored with partial replacement by Vitrified Tiles Sludge (VTS), an industrial waste. In this experimental study, expansive soils samples are collected from Palakol town in the West Godavari District, Andhra Pradesh, India. The experiments showed significant volume changes in the soil with a change in water content, corresponding decrease in strength and significant increase in compressibility. The current experimental investigation studies the variation in the geotechnical characteristics of expansive soil modified with sludge formed by crushing vitrified tiles (VTS) in aqueous medium. Our study reveals that there is a significant decrease in compressibility characteristics of the clay with an increase in the proportion of vitrified tile sludge. The composite soil proves to be good construction material for construction of various civil engineering structures such as embankment, earthen dams, and runways wherever the decrease in swelling and plasticity are the real targets.
\end{abstract}

Keywords: Expansive soil $\cdot$ Atterberg limits $\cdot$ Soil stabilization $\cdot$ Vitrified tiles sludge

\section{Introduction}

The study area comprising part of Godavari delta extends over Andhra coast from Rajahmundry to Narsapur. Geographically, the area lies between, $81.8040^{\circ} \mathrm{E}$ to $81.6966^{\circ}$ E Long. and $16.4330^{\circ} \mathrm{N}$ to $17.0005^{\circ} \mathrm{N}$ Lat. and is covered by Survey of India topographical map Nos. 65 D \& Hand 66 A \& E. The north-western boundary touches the Madras- Calcutta grand trunk road passing through Vijayawada, Eluru and Rajahmundry. Administratively, the area falls in the jurisdiction of East and West Godavari districts of Andhra Pradesh. The delta is nearly flat and highly irrigated. The geological succession of the area comprises alluvial deposits (Recent period), Deccan trap (Eocene), Gondawana (Carboniferous), Cuddapah-Kurnool and Dharwars (Cambrian) and granite-gneisses (Archaean). The area receives rainfall both in south-west and 
north-east monsoon periods. The actual rain fall in the East Godavari District is $449.7 \mathrm{~mm}$ and the actual rain fall in the West Godavari district is $442.0 \mathrm{~mm}$. The main soil groups are Black cotton soils with the subgroup Typical Pellusterts and Chromusterts with the essential clay mineral as fine montmorillonitic. The area under study has many tile factories where in untreated effluent comprising sludge made up of grounded tiles and water is left into the cultivable land rendering them nearly useless.

Vitrified Tiles are the latest and largest growing industry alternate for many tiling requirements across the globe with far superior properties compared to natural stones and other manmade tiles. India and China are the largest regions to contribute to the 6900 million square meters of production every year. With an annual growth rate of $20 \%$ worldwide and $25 \%$ in India, Vitrified tile is the fastest growing segment in the tile industry. Vitrified tiles own $12 \%$ share of the overall tile production across the world. With the increase in production of vitrified tiles in India, there is growing concern about the huge generation of tile polishing dust.

The raw material composition of Vitrified tiles is:

- Quartz of $99 \%$ Silica,

- Potash Feldspar of $12 \%$ to $14 \%$ Alkalis,

- Soda Feldspar of $12 \%$ to $14 \%$ Alkalis,

- Strengthening agent, China clay, body stains for producing in various colors.

VTS is collected from a tile factory situated at Narayanapuram Village, Ungutur Mandal, West Godavari, Tadepalligudem - 534407, Andhra Pradesh, India. The physical properties of Vitrified Tile Sludge (VTS) are given in the Tables 1 and 2 below.

Table 1. Chemical properties of Vitrified Tile Sludge (VTS)

\begin{tabular}{l|l}
\hline Materials & VTS (\%) \\
\hline $\mathrm{SiO}_{2}$ & 63.29 \\
\hline $\mathrm{Al}_{2} \mathrm{O}_{3}$ & 18.29 \\
\hline $\mathrm{Fe}_{2} \mathrm{O}_{3}$ & 4.32 \\
\hline $\mathrm{CaO}$ & 4.46 \\
\hline $\mathrm{MgO}$ & 0.72 \\
\hline $\mathrm{P}_{2} \mathrm{O}_{5}$ & 0.16 \\
\hline $\mathrm{K}_{2} \mathrm{O}$ & 2.18 \\
\hline $\mathrm{Na}_{2} \mathrm{O}$ & 0.75 \\
\hline $\mathrm{SO}_{3}$ & 0.10 \\
\hline $\mathrm{CL}^{-}$ & 0.005 \\
\hline $\mathrm{TiO}_{2}$ & 0.61 \\
\hline $\mathrm{SrO}_{2}$ & 0.02 \\
\hline $\mathrm{Mn}_{2} \mathrm{O}_{3}$ & 0.05 \\
\hline $\mathrm{L}^{\circ} \mathrm{O} . \mathrm{I}$ & 1.61 \\
\hline
\end{tabular}

The current experimental study is concerned with the selection of approximate type of soil to achieve a very high degree of compaction and to expose the compaction properties of clay. The results of the study can provide thoughts for applying clay soil in various applications of soil stabilization process. 
Table 2. Engineering properties of pure vitrified tile sludge

\begin{tabular}{l|c}
\hline$\%$ Medium sand & 1.43 \\
\hline$\%$ Fine sand & 95.7 \\
\hline$\%$ Silt and Clay & 1.07 \\
\hline Specific gravity & 2.46 \\
\hline MDD $(\mathrm{g} / \mathrm{cc})$ & 1.58 \\
\hline OMC $(\%)$ & 19.4 \\
\hline
\end{tabular}

\subsection{Objectives of the Study}

The following are the main objectives for the present study:

(a) Evaluate the limiting VTS content to reduce the plasticity i.e., Atterberg limits viz., Liquid limit by $20 \%$ and Plastic limit by $10 \%$ off the native clayey soil

(b) To increase the sub grade soil stiffness of the soil by at least $25 \%$.

\section{Literature Review}

Al-Rawasa et al. (2005) has tried to stabilize expansive soil with lime, cement, combinations of lime and cement, sarooj (Artificial pozzolana), heat treatment and have found that with the addition of $6 \%$ lime, both the swell percent and swell pressure reduced to zero and heat treatment reduced swelling potential to zero. Al-Rawas et al. (2002) investigated the effectiveness of using cement by-pass dust, copper slag, granulated blast furnace slag, and slag-cement in reducing the swelling potential and plasticity of expansive soils. Bell (1989) through his experiments on Clayey soil showed that addition of a small percentage of lime enhanced many of the engineering properties of the soil. Boardman et al. (2001) with the help of two clay minerals assessed to assess the time-dependent effects of mineral structural chemistry on the lime-clay reaction. Briptive (2004) emphasized the need of a quick or simple test to show the amount of lime required to react chemically with a soil to bring about these physical changes to an optimum degree. Buhler and Cerato (2007) and Modak et al. (2012) mixed highly expansive soil with lime and class $\mathrm{C}$ fly ash to study the plasticity reduction in highly expansive natural clays from Idabel, Oklahoma. Çokça (2001) has used, high-calcium and low-calcium class $\mathrm{C}$ fly ashes from the Soma and Tuncbilek thermal power plants, respectively, in Turkey, for stabilization of an expansive soil. An evaluation of the expansive soil-lime, expansive soil-cement, and expansive soil-fly ash systems is presented. Cristelo et al. (2013) have studied the effects of sodium-based alkaline activators and class F fly ash on soil stabilization. Eades (1966) tried to show through simple test, the amount of lime required to react chemically with a soil to bring about these physical changes to an optimum degree. Edil et al. (2006) have evaluated the effectiveness of self-cementing fly ashes derived from combustion of sub-bituminous coal for stabilization of soft fine-grained soils. Addition of fly ash resulted in appreciable increases in the California bearing ratio (CBR). Ferguson (1993) had reported that Ash treatment can effectively reduce the swell potential of fat clay 
soils and increases the sub grade support capacity of pavement sub grades. Greeves (1996) used expansive black cotton soil to assess the influence of ambient temperature in the progress of lime-soil reactions. Higgins (2005) reported the incorporation of ground granulated blast furnace slag to combat the soil expansion. Hunter (1988) studied the expansive reactions between lime and sulfate-bearing clay soils and reported that the long-term pozzolanic chemistry of normal lime-soil reactions found to be disrupted while Cation exchange, agglomeration, and carbonation are unaffected. Jones and Holtz (1973) studied the relationship between the mineralogical composition and water chemistry and their relationship to geotechnical properties and engineering structures failures. Kamon and Nontananandh (1991) prepared a product by burning industrial wastes along with lime to produce a by-product having cementing characteristics and showed that the resulting by-product is of promise for use in stabilizing a loam soil. Khattab et al. (2007) have evaluated the long-term stability characteristics of lime-treated expansive soils to improve the properties of expansive soils. Matsuo and Kamon (1981) have investigated a new stabilization method of soft clay soils using multivalent cations, trivalent cations, e.g. $\mathrm{Fe}^{3+}$ and $\mathrm{Al}^{3+}$. The beneficial effects of this treatment are clarified not only for engineering properties but also for microscopic mechanisms (ionization process and aggregating phenomenon). McCarthy et al. (2014), investigated the engineering and durability properties of lime-stabilized soils treated with low-lime fly ash to limit swelling (heave) due to sulphate, associated with the ground improvement process. Turkoz et al. (2014) have evaluated the effect of magnesium chloride $\left(\mathrm{MgCl}_{2}\right)$ solution on the engineering properties of clay soils. The results show that dispersive and expansive clay soils can be effectively improved using an additive $\mathrm{MgCl}_{2}$ solution. Puppala (2003) investigated with class $\mathrm{F}$ fly ash, sulphate-resistant cement, ground granulated blast furnace slag (GGBFS) and lime mixed with fibers as potential stabilizers in enhancing the strength and volume change properties of soft, expansive and sulphate-rich soils. Petry and Armstrong (1989) had developed performance-based testing of chemical stabilizers that simulate field conditions. The situations included a physical erosion test to determine dispersion of clays that have been treated, two swell test preparation sequences simulating injection of chemicals into clays, a wet-dry test sample preparation using field gradation specifications, and a three-dimensional swell test for stability of treated clays when subjected to wetting. Petry (1997) used Chemical stabilizing agents to improve the behavior of earth materials. Rao and Subba Rao (1994) have discussed the cause of ground heave of an inherently non-swelling, kaolinite-rich red soil (from Bangalore, India) due to prolonged spillage of concentrated (40\%, weight/weight solution) caustic soda (sodium hydroxide) solution into the sub-soil through cracked drains in an industrial establishment. Treatment of the contaminated ground with $5 \%$ ferric chloride solution and simultaneously measures to minimize caustic soda solution spillage mitigate the soil against heave from caustic soda attack. Reddy et al. (2015) have employed three types of additives viz., (a) Cementitious: lime and fly ash (b) Non-cementitious: stone dust, and (c) Chemical additives: $\mathrm{CaCl}_{2}$ and $\mathrm{Na}_{2} \mathrm{SiO}_{3}$ to evaluate the performance of stabilized expansive soils. They investigated the influence of valence of cations (viz., monovalent, divalent and trivalent) and mean particle diameter of additive(s) on percentage reduction of swelling characteristics. Their results revealed that chemical additives exhibit superior performance over cementitious and non-cementitious 
additives in reducing the swelling characteristics. Brooks (2009) studied the suitability of expansive soil as a construction material using rice husk ash (RHA) and flyash. Saha and Saha (1991) have upgraded expansive soil as a construction material using rice husk ash (RHA) and flyash, a cost comparison was made for the preparation of the sub-base of a highway project with and without the admixture stabilizations. When the RHA content of $12 \%$ and a flyash content of $25 \%$, Unconfined Compressive Stress increased by $97 \%$ while CBR improved by $47 \%$. Sivanna (1976) had studied the problem of damage to structures in expansive soils world wide and have proposed that sodium carbonate and calcium carbonate is stabilizing a black cotton soil. Sivapullaiah studied the effect of electrolytes on the shear strength of clayey soils. Abood et al. (2007) had investigated the effect of adding different chloride compounds including $\left(\mathrm{NaCl}, \mathrm{MgCl}_{2}, \mathrm{CaCl}_{2}\right)$ on the engineering properties of silty clay soil. The increase in the percentage of each of the chloride compounds increased the maximum dry unit weight and decreases the optimum moisture content. While the liquid limit, plastic limit and plasticity index decreased with the increase in salt content, the unconfined compressive strength increased with the increase in salt content. Nalbantoglu (2001) has shown that Fly ash treatment has tremendous potential as an economical method for the stabilization of the soil. Significant reduction in the swell potential and an increase in the hydraulic conductivity values were reported.

\section{Need for Study}

From the literature review it is observed that: Almost all of the researchers have studied the effect of (1) Industrial Byproducts (Fly ash, Rice Husk Ash), (2) Chemical additives (Lime, Caustic Soda, Calcium Carbonate, Sodium Carbonate, Magnesium Chloride, Mono-valence, Divalent and trivalent compounds).

Effect of treatment on soil properties like specific gravity, liquid limit, plastic limit, plasticity index, grain size analysis, shear strength of soil and bearing resistance have been studied. Long-term behavior of soil like consolidation properties, hydraulic conductivity and resilient modulus has not been studied by most researchers.

- There are many methods of laboratory experimentation to inhibit soil expansion but very few field methods to forecast soil expansion are available.

- Stress - strain behavior of the modified soil needs to be studied.

- Very minimal or no research has been conducted on industrial waste sludge despite the fact that they constitute environmental hazards and could have their usefulness in soil stabilization.

\section{Experimental Studies}

The methods adopted for the present study of investigation are presented below: Natural moisture content of the soil samples is determined as per IS: 2720 (Part II) "Methods of Test for Soils" (Water Content), BIS, New Delhi. The specific Gravity of the soil is determined as per 38. IS 2720 Part-III/Section 2 (1997), "Methods of Tests 
for soils" (Specific Gravity), BIS, New Delhi. The grain size analysis is conducted as per IS 2720 Part-IV (1995), "Methods of Tests for soils" (Grain Size Analysis), BIS, New Delhi.

The liquid, plastic limit (Atterberg's limits) are determined as per IS 2720 Part-V (1995), "Methods of Tests for soils" (Atterberg Limits), BIS, New Delhi. THE maximum unit weight and optimum moisture content for a given effort of compaction are obtained as per IS 2720 Part-VIII (1997), "Methods of Tests for soils" (Proctor's Compaction Test), BIS, New Delhi. The bearing resistance of the soil in soaked and un-soaked conditions is determined as per IS: 2720 (Part-16) (1979), "Methods of Tests for soils" (California Bearing Ratio), BIS, New Delhi. In CBR (Fig. 1) testing the rate of penetration of the plunger was kept at $1.25 \mathrm{~mm} / \mathrm{min}$ and Proving ring capacity is $10 \mathrm{KN}$. Soaked CBR values at $2.5 \mathrm{~mm}$ and $5 \mathrm{~mm}$ penetration were calculated for all the samples.

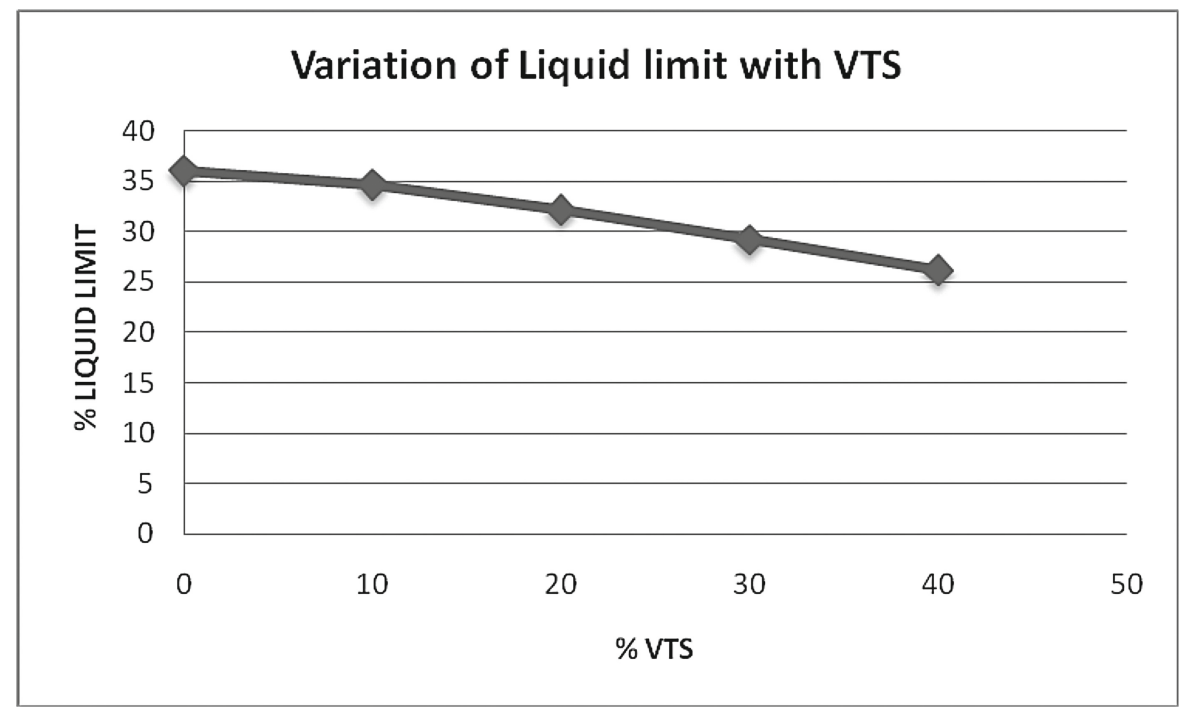

Fig. 1. Liquid limit of clayey soil admixed with different proportions of VTS

While the Unconfined Compressive strength of the soil is determined as per IS 2720 (Part-10) (1991), "Methods of Test for Soils", (Unconfined Compressive Strength), BIS, New Delhi. UCS testing is based on the fact that the minor principal stress is zero and the angle of internal friction of the soil is assumed to be zero. Strain controlled testing was followed and a strain rate of $1 \%$ per minute is used. At the time of testing loading is continued until the load on the specimen begins to decrease or until at least $20 \%$ of strain has been reached. In this case for the sample of $76 \mathrm{~mm}$ height $20 \%$ strain amounts to $0.2 \times 76=15.2 \mathrm{~mm}$.

Specimens for CBR and UCS testing are prepared at predetermined water content and unit weight. The free swell Index is determined as per IS: 2720 Part XL (1977), "Methods of Test for Soils", Determination of Free Swell Index of Soils, BIS, New Delhi. 


\section{Results and Discussion on Results}

The native clayey soil is admixed with VTS by varying its proportion and the optimum content of the VTS is determined (Table 3 ). The admixed proportions of VTS considered in this study are $0 \%, 10 \%, 20 \%, 30 \%$ and $40 \%$.

Table 3. Summary of the laboratory test results

\begin{tabular}{l|l}
\hline Sample & Palakol \\
\hline$\%$ Sand & 6 \\
\hline$\%$ Silt & 32 \\
\hline \% Clay & 62 \\
\hline Moisture content, n.m.c (\%) & 15.38 \\
\hline Specific gravity & 2.71 \\
\hline Liquid limit & 66.4 \\
\hline Plastic limit & 32 \\
\hline OMC, $\%$ & 22 \\
\hline Max dry unit weight $\left(\gamma_{\mathrm{d}}\right)_{\max }(\mathrm{g} / \mathrm{cc})$ & 1.56 \\
\hline Soaked CBR for $2.5 \mathrm{~mm}$ penetration & $1.8 \%$ \\
\hline Unsoaked CBR & $3.2 \%$ \\
\hline DFS & 150 \\
\hline
\end{tabular}

Table 4. Summary of the test results obtained with different proportions of the VTS with Clayey soil

\begin{tabular}{l|l|l|l|l|l}
\hline VTS (\%) & 0 & 10 & 20 & 30 & 40 \\
\hline Liquid limit (\%) & 36.02 & 34.67 & 32.12 & 29.17 & 26.14 \\
\hline Plastic limit (\%) & 33.33 & 28.57 & 25 & 23.07 & 20 \\
\hline O.M.C (\%) & 18.2 & 17 & 15 & 14.4 & 10 \\
\hline Max dry unit weight (g/cc) & 1.61 & 1.62 & 1.635 & 1.64 & 1.66 \\
\hline CBR for 2.5 mm penetration & $2.50 \%$ & $2.60 \%$ & $5.20 \%$ & $3.80 \%$ & $3.72 \%$ \\
\hline UCS & 6.68 & 7.06 & 8.5 & 8.24 & 8.18 \\
\hline
\end{tabular}

The following paragraphs describe the laboratory results (Table 4).

The above values are plotted against the different proportions of VTS admixed with the Clayey soil. The following are the observations found from these tests:

(a) As the admixed proportion of VTS increases from $10 \%$ to $40 \%$, the liquid limit of the clayey soil is decreasing gradually (Fig. 1). The curve observed as falling trend. The similar trend is also observed in case of plastic limit of the soil (Fig. 2).

(b) In contrast, the dry unit weight of the soil is gradually increasing with slight reduction with OMC (Fig. 3). 
(c) The soaked CBR values are gradually increased from $2.34 \%$ to $5.04 \%$ with $0 \%$ and $20 \%$ replacement and there onwards the CBR values are found to be decreasing with further increasing of the VTS content (Fig. 4).

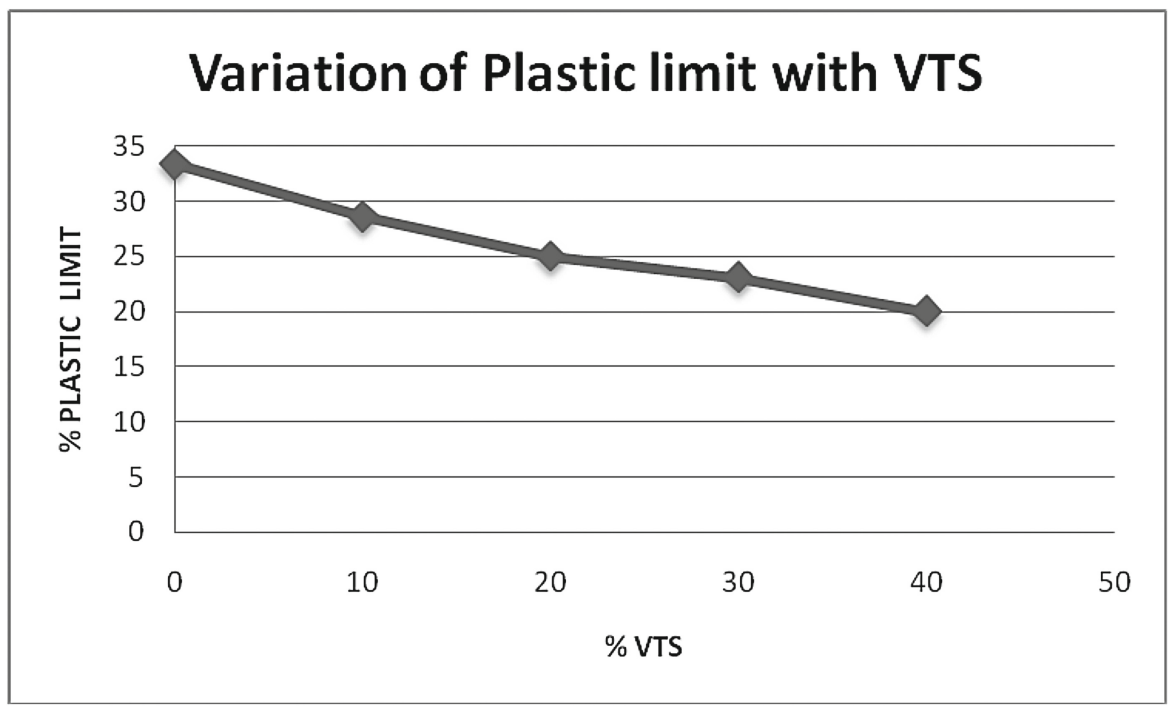

Fig. 2. Plastic limit of the soil obtained with different proportions with VTS

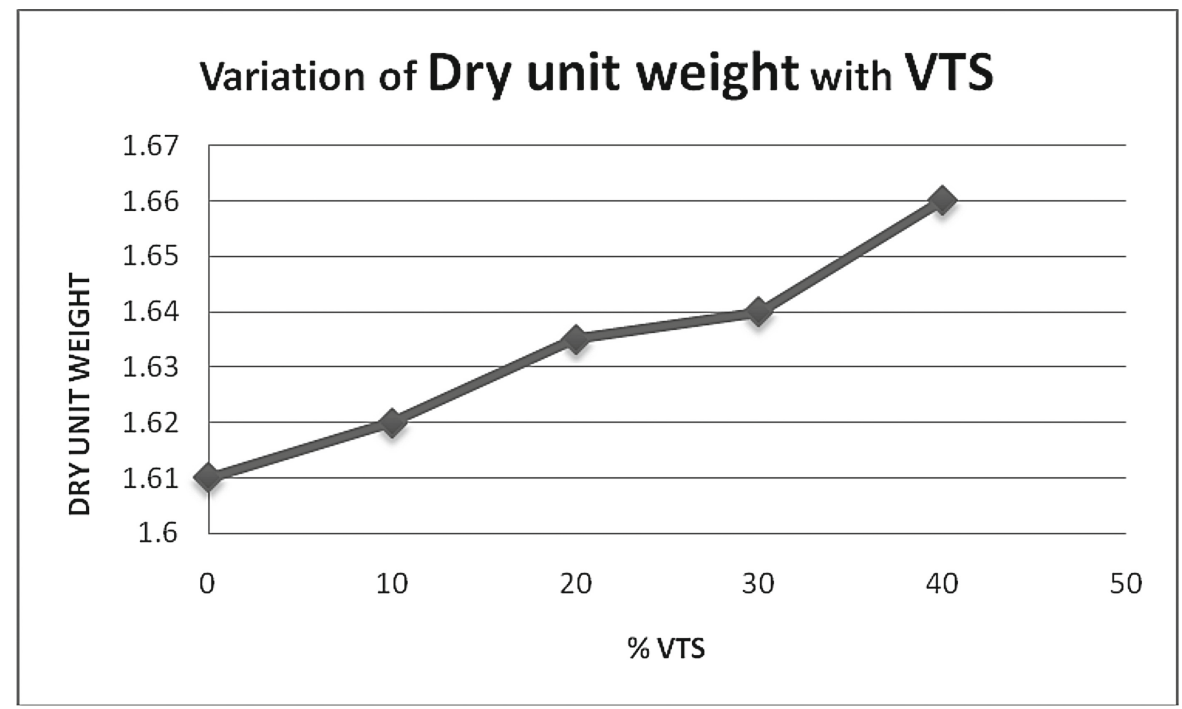

Fig. 3. Dry unit weight of the soil obtained with different proportions with VTS 


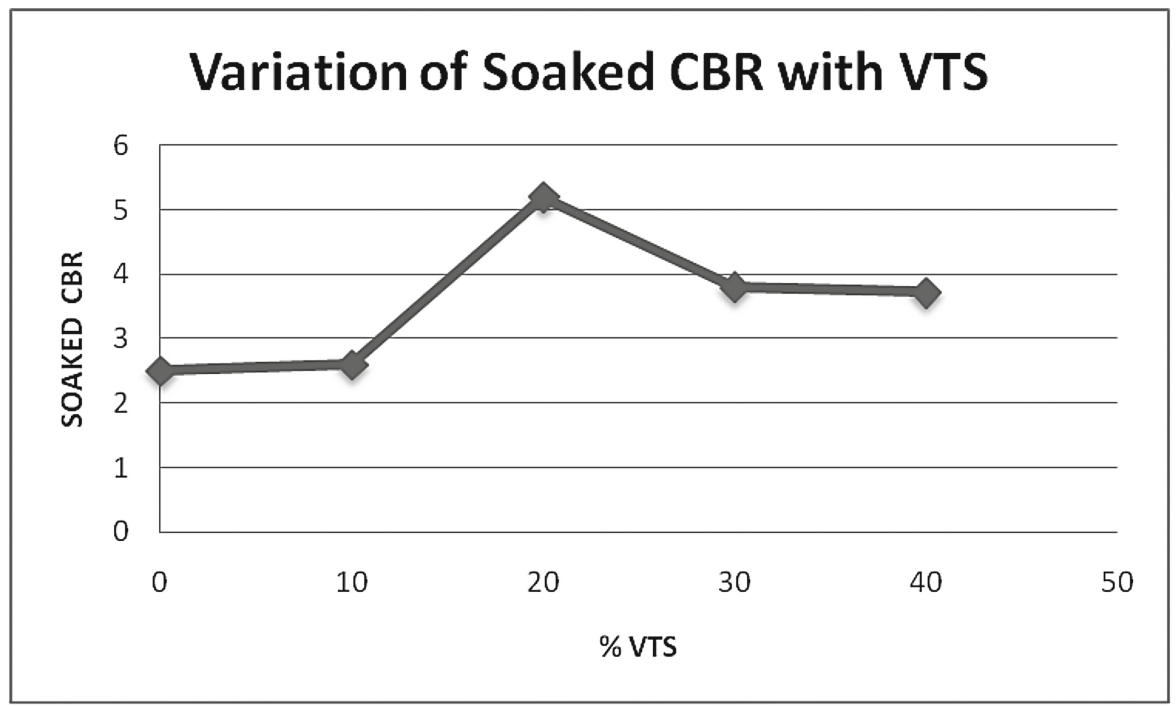

Fig. 4. Soaked CBR values of soil obtained with different proportions of VTS

(d) The UCS values are gradually increased from $6.68 \%$ to $8.5 \%$ with $0 \%$ and $20 \%$ replacement and thereafter, the UCS values are found to be decreasing with further increasing of the VTS content (Fig. 5).

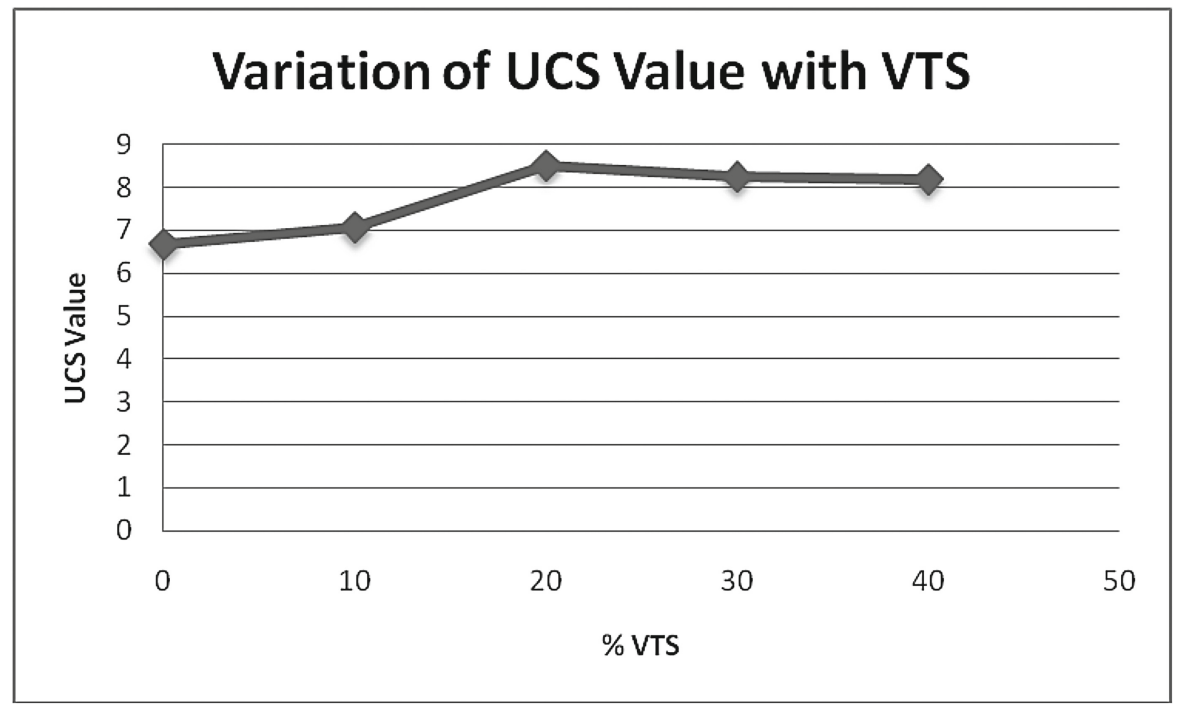

Fig. 5. UCS values of soil obtained with different proportions of VTS 


\section{Conclusions}

The following are the conclusions drawn from the present study:

(a) Addition of varied Vitrified Tile Sludge (VTS) content has improved the properties of the clay sample.

(b) Replacement of Vitrified Tile Sludge by $20 \%$ is found to be optimum.

(c) The flow characteristics, plasticity characteristics and shrinkage characteristics of the soil sample are gradually decreasing with increase in the percentage of VTS in the clay sample.

(d) At the optimum VTS content of $20 \%$ replacement, the maximum dry density, soaked CBR value and UCS values are obtained as $1.635 \mathrm{gm} / \mathrm{cc}, 5.2 \%$ and 85 , respectively.

Hence, it is concluded that the VTS as a waste product can also be used for soil stabilization purpose and the obtained results are based on this single study, further investigation is required to confirm the findings.

Acknowledgments. We sincerely acknowledge Ms. Ch. Tanuja, Assistant Professor at English in the Department of Basics Science \& Humanities, Sri Vasavi Engineering College, Tadepalligudem, West-Godavari District, Andhra Pradesh, India, for rigorous round of proof reading at English.

\section{References}

Al-Rawas, A., et al.: A comparative evaluation of various additives used in the stabilization of expansive soils. Geotech. Test. J. 25(2), 199-209 (2002)

Al-Rawasa, A.A., et al.: Build. Environ. 40(5), 681-687 (2005). Elsevier

Bell, F.G.: Lime stabilization of clay soils. Bull. Int. Assoc. Eng. Geol. 39, 67 (1989)

Boardman, D.I., et al.: Development of stabilization and solidification in lime-clay mixes. Geotechnique 51, 533-543 (2001)

Britpave: Stabilized soils as sub-base or base for roads and other pavements. The British In-situ Concrete Paving Association, Camberley BP/08 (2004)

Buhler, R.L., Cerato, A.B.: Stabilization of Oklahoma expansive soils using lime and class c flyash. In: Problematic Soils and Rocks and In-situ Characterization, GSP 162, pp. 1-10. ASCE (2007)

Çokça, E.: Use of class C flyash for the stabilization of an expansive soil. J. Geotech. Geoenviron. Eng. 127(7), 568-573 (2001). ASCE

Cristelo, N. et al.: Effects of alkaline-activated fly ash and portland cement on soft soil stabilization. Acta Geotech. (2013). doi:10.1007/s11440-012-0200-9

Eades, J.L., Grim, R.E.: A quick test to determine requirements for lime stabilization.Highw. Res. Board Bull. 139(1966), 61-72 (1966)

Edil, T., et al.: Stabilizing soft fine-grained soils with fly ash. J. Mater. Civ. Eng. 18(2), 283-294 (2006)

Ferguson, G.: Use of self commenting flyash as a soil stabilizing agent. Geotechnical Special Publication, vol. 36. ASCE, New York, pp. 1-15 (1993) 
Greeves, H.M.: An introduction to lime stabilization. In: Proceedings, Seminar on Lime Stabilization, Loughborough University, pp. 5-12. Thomas Telford, London (1996)

Higgins, D.D.: Soil Stabilisation with ground granulated blastfurnace slag. Cementitious Slag Makers Association (CSMA) (2005)

Hunter, D.: Lime-induced heave in sulfate-bearing clay soils. J. Geotech. Eng. 114(2), 150-167 (1988). ASCE

IS: 2720 Part XL: Methods of test for soils, Determination of Free Swelkl Index of Soils, BIS, New Delhi (1977)

IS: 2720 Part-16: Methods of tests for soils (California Bearing Ratio), BIS, New Delhi (1979)

IS 2720 Part-10: Methods of test for soils, (Unconfined Compressive Strength), BIS, New Delhi (1991)

IS 2720 Part-IV: Methods of tests for soils (Grain Size Analysis), BIS, New Delhi (1995)

IS 2720 Part-V: Methods of tests for soil (Atterberg Limits), BIS, New Delhi (1995)

IS 2720 Part-III: Methods of tests for soils (Specific Gravity), BIS, New Delhi (1997)

IS 2720 Part-VIII: Methods of tests for soils (Proctor's Compaction Test), BIS, New Delhi (1997)

Jones, D.E., Holtz, W.G.: Expansive soils- the hidden disaster. Civil Engg. 43(8) (1973)

Kamon, M., Nontananandh, S.: Combining Industrial Wastes with Lime for Soil Stabilization. J. Geotech. Eng. 117(1), 1-17 (1991). ASCE

Khattab, S.A.A., et al.: Long term stability characteristics of a lime-treated plastic soil. J. Mater. Civil Eng. 19(4), 358-366 (2007)

Matsuo, S., Kamon, M.: Soil stabilisation by multivalent cations. In: Proceedings of the 10th ICSMFE, Stockholm, vol. 3, pp. 735-738 (1981)

McCarthy, M.J., Csetenyi, L.J., Dhir, R.K.: Engineering and durability properties of fly ash treated lime-stabilised sulphate-bearing soils. Eng. Geol. 174, 139-148 (2014). Elsevier

Turkoz, M., et al.: The effect of magnesium chloride solution on the engineering properties of clay soil with expansive and dispersive characteristics. Appl. Clay Sci. 101, 1-9 (2014)

Modak, P.R., et al.: Stabilization of black cotton soil using admixtures. Int. J. Eng. Innovative Technol. (IJEIT) 1(5), 1-3 (2012)

Pappula, J., Wattanasanticharoen, E., Punthutaecha, K.: Experimental evaluations of stabilisation methods for sulphate-rich expansive soils. Proc. Inst. Civil Eng. Ground Improv. 7(1), 25-35 (2003). ISSN 1755-0750

Petry, T.M., Armstrong J.C.: Stabilization of expansive clay soils, RR-1219, TRB, pp. 103-112 (1989)

Petry, T.M.: Performance based testing of chemical stabilizers. Transp. Res. Rec. Transp. Res. Board Nat. Acad. 1589, 36-41 (1997)

Rao, S.M., Subba Rao, K.S.: Ground heave from caustic soda solution spillage - a case study. J. Soils Found. 34(2), 13-18 (1994)

Reddy, N.G., et al.: Evaluating the influence of additives on swelling characteristics of expansive soil. Int. J. Geosynthetics Ground Eng. 1(1), 7 (2015). Springer. doi:10.1007/s40891-0150010-x. ISSN 2199-9260

Brooks, R.M.: Soil stabilization with flyash and rice husk ash. Int. J. Res. Rev. Appl. Sci. 1(3), 209-217 (2009)

Saha, S., Saha, P.: Improvement of soils by use of chemicals. In: IGC - 91, Surat, vol. 1, pp. 429432 (1991) 
Sivanna, G.S.: Strength and Consolidation Characteristics of Black Cotton Soils with Chemical Additives- $\mathrm{CaCl} 2$ \& $\mathrm{KOH}$, Report Prepared by Karnataka Engg. Research Station, Krishnarajasagar, India, pp. 21-27 (1976)

Abood, T.T., et al.: Stabilization of silty clay soil using chloride compounds. J. Eng. Sci. Technol. 2(1), 102-109 (2007)

Nalbantoglu, Z., Gucbilmez, E.: Improvement of calcareous expansive soils in semi-arid environments. J. Arid Environ. 47(4), 453-463 (2001). Elsevier B.V 